\title{
Implementation of Scientific Approach in Physics
}

\author{
Wahyu Arini \\ Physics Education Study Program STKIP-PGRI Lubuklinggau \\ Jalan Mayor Toha Taba Pingin, Lubuklinggau City, 31628, Indonesia \\ *Correspondence: wahyuarini02@gmail.com
}

\begin{tabular}{ll}
\hline & Abstract \\
\hline Keywords: & This research is entitled "The Implementation of Scientific Approaches in Physics \\
Implementation & Learning in Class X of SMA Negeri 9 Lubuklinggau". This study aims to determine \\
Scientific Approach & the completeness of physics learning outcomes of class X students of SMA Negeri 9 \\
Learning Outcomes & lubuk linggau after implementing the Scientific approach. The research method used \\
& was quasi-experimental. This research uses a scientific approach, the scientific \\
& approach has stages of observing, asking, trying, reasoning, and communicating. The \\
& learning material in this research is measurement. The population in this study was all \\
& class X SMA Negeri 9 Lubuklinggau and the sample was class X IPA 2, amounting to \\
& 36 students and taken randomly. The test instrument uses 7 essay questions and \\
& observation sheets to collect data about all activities or student activity processes \\
& during learning. Based on the results of data analysis with t-test, it was obtained that t- \\
& count = 4,33 and t-table = 1,697, this shows that t-hitung $\geq$ t-tabel then Ha was \\
& received and Ho was rejected. Thus the hypothesis proposed in this study can be \\
& accepted as true. So it can be concluded the physics learning outcomes of class X \\
students of SMA Negeri 9 Lubuklinggau after applying the Scientific approach is & \\
significantly completed.
\end{tabular}

To cite this article:

Arini, W. (2020). Implementation of scientific approach in physics. Thabiea : Journal of Natural Science Teaching, Vol. 3(2), 151-161.

\section{Introduction}

Education is a necessity that must be met in people's lives, in a nation and the homeland. Education can develop personal skills, better thought, and behavior. The school as a formal education executive that handles a wide range of characterizing students requires innovative and creative learning and teaching process from various parties. Teachers are finally in the spotlight because they are at the forefront of direct learning with students in the learning process. In such conditions, teachers are required to develop skills, knowledge, and give birth to new things, teachers who can innovate means that they can develop the creative ideas they have (Purwadhi, 2019).

Learning activities are part of the educational process in schools, learning activities play an important role in developing reasoning abilities and skills, and shaping the attitudes of students. According to (Rusman, 2019), effective learning includes an adequate understanding of how and why activities lead to the implementation of learning, and the factors that influence their effectiveness. The main criteria for a learning process that can be said to be successful are predetermined goals. The process to achieve these goals must pay attention to several factors, one of which is having the ability to learn. Effective in learning physics concerning the path, effort, technique, strategy used in achieving the right goals, and quickly 
in the physics learning process. Similarly, many formulas and calculations in complicated problem solving, so that students grow the impression that physics is a lesson that is difficult to learn and less desirable especially for groups of students who have the low ability (Rusman, 2013).

One of the decisive factors for success in learning is teachers, therefore the ability of teachers to avoid learning needs to be improved, to obtain results that are suitable for educational purposes. In conveying physical material the teacher must make physics lessons interesting so that the difficulties of the students in the concept of understanding the material do not pose problems to the outcome of learning (Aunurrahman, 2016). Physics education is one of the subjects that is considered to have an important role in improving children's creativity and thinking processes. According to physics learning, educators should actively involve students. Students do not just listen to and take notes on educators' explanations and do not just count but focus more on the reasoning process, namely by learning physics students can think creatively and systematically, not just counting quickly in their heads. Therefore, physics knowledge must be mastered as early as possible by students (Soenarto, 2011).

The scientific approach was introduced in world education in America in the late 19th century, as an approach to formalistic laboratory methods that lead to scientific facts (Sudirman, 2017). This scientific approach has the attribute of "doing science". This approach facilitates the development of a curriculum in improving the learning process, namely by breaking the process down into more detailed steps containing instructions for students in carrying out learning activities (Nurlatifah, 2019). A teacher must have skills in managing his class. Also, the skills a teacher must possess are skills for evaluating and assessing his or her students (Simsek, 2017). However, the facts show that there are still many teachers who experience difficulties in carrying out a scientific approach. It can be seen from several research results, such as the research conducted by Mayang (2015) which reveals that most science teachers have not fully understood the scientific approach in the 2013 curriculum. While teaching, many teachers still explain and record on the board, so that the learning process is not centered on students, but still teacher-centered (Nenotaek, 2019).

Based on the results of direct observations with the physics subject teacher at SMA Negeri 9 Lubuklinggau, it was found that students' competence in understanding physics material was still lacking so that students still had difficulty working on questions related to learning material. Then the learning process of physics still often uses conventional methods and students consider that physics is difficult learning because it involves a lot of calculations or formulas that affect the learning outcomes of students are still relatively low. This can be seen from the daily return data of one class X MIPA that follows the learning process only 14 students (40\%) Achieving minimum submission criteria (KKM) and 22 students (60\%) That has not reached the value of the minimum submission criteria (KKM) that has been determined by the school is 75 . So there are still a lot of students who need to follow remedial to improve their grades. To overcome such problems, an effective approach that can support students in improving the outcome of physics learning is by applying a scientific approach (scientific) which is an approach in the implementation of the 2013 curriculum (Sani, 2014). Thus, scientific approaches (scientifically) are expected to solve problems in the learning process that has been done (Rhosalia, 2017). 


\section{Method}

The research method is the method used by researchers in collecting research data (Arikunto, 2010). Meanwhile, Sugiyono states that the research method is a scientific way to obtain data with specific purposes and uses (Sugiyono, 2012). The type of research used in this research is quantitative with quasi-experimental research methods.

The experiment group uses a scientific approach, In learning through a scientific approach the process of building students' understanding of the material by constructing their own understanding and emphasizing the students to learn measurement and building problemsolving skills, this is regardless of the ability of each individual different way of learning and level of ability. In the learning model with a scientific approach, the questions that invite students to think about the problem-solving skills are taught in the final stages of learning and are often missed due to the time in the process of constructing students' understanding longer, so the problem-solving ability of students has not been maximized. The affective side of scientific learning activities have not built Self Regulated Learning because there is no part in the scientific study in terms of motivating to learn to students so that students are more independent and motivated in learning physics, so that when students have the ability to face various problems and problems in learning physics (Sudirman, 2017).

The implementation of learning uses a scientific approach to conduct excavation, planting, enhancement, and development of knowledge through research, from this activity, will form an analytical thinking pattern and will bring the facts of the phenomenon that occurs. Meanwhile, scientific learning is built from learning materials based on facts or phenomena that can be explained by certain logic or reasoning done by teachers, student responses, and educational interactions; encourage and inspire students to think critically, analytically, and appropriately in identifying, understanding, and solving the problems, and being able to apply; To encourage and inspire students to be able to think hypothetically in seeing the differences, similarities, and relationships between elements and be able to understand, apply, and develop a rational and objective mindset in responding to the subject matter; based on empirical concepts, theories and empirical facts that can be justified; and learning objectives are formulated in a simple and clear, but interesting in the presentation (Wahyono, 2017).

The design in this study is a one-group pretest-posttest design, where treatment is carried out the one-time measurement in front (pre-test) before the treatment (treatment) and after that the measurement again (post-test). In this design, the researcher performs pretreatment on one object under study, then the researcher gives a certain treatment. The measurement was taken a second time. According to Suharsimi, research instruments are tools or used by researchers in collecting data so that the work is easier and the results are better, in a more accurate, complete systematic sense so that it is easier to process (Suharsimi, 2010). Test instruments used to measure the quality of the tests were used as a measure of test requirements for validity, reliability, level of difficulty, and differentiation.

Based on the results of the calculation of the recapitulation analysis of the validity of the 11 items, only 7 were valid and 4 were invalid. From the calculations that have been obtained from the instrument test data, namely 7 valid questions used for research as the pretest and post-test questions. There is also very high validity, there is 1 question, high validity has 4 questions, medium validity has 2 questions, low validity has 2 questions and very low 
validity has 2 questions. The recapitulation of the results of the analysis of the validity of the items can be seen in table 1 .

Table 1. Results of the Validity Analysis of the Instrument Trial Test

\begin{tabular}{ccccc}
\hline $\begin{array}{c}\text { Question } \\
\text { Number }\end{array}$ & $\mathbf{r}_{\mathbf{x y}}$ Value & $\boldsymbol{t}_{\text {count }}$ Value & $\boldsymbol{t}_{\text {tabel }}$ Value & Criteria \\
\hline 1 & 0,44 & 4,85 & 2,056 & Medium validity \\
\hline 2 & 0,66 & 2,34 & 2,056 & High validity \\
\hline 3 & 0,19 & 1,14 & 2,056 & Very low validity \\
\hline 4 & 0,25 & 0,93 & 2,056 & Low Validity \\
\hline 5 & 0,24 & 1,31 & 2,056 & Low Validity \\
\hline 6 & 0,76 & 5,90 & 2,056 & High validity \\
\hline 7 & 0,61 & 3,69 & 2,056 & High validity \\
\hline 8 & 0,85 & 4,21 & 2,056 & Very high validity \\
\hline 9 & 0,65 & 4,45 & 2,056 & High validity \\
\hline 10 & 0,59 & 3,82 & 2,056 & Medium validity \\
\hline 11 & 0,01 & 0,05 & 2,056 & Very low validity \\
\hline
\end{tabular}

A reliable instrument means that an instrument that is used several times to measure the same object will produce the same data (Sugiyono, 2015). By using the alpha formula, the reliability coefficient value is 0,81 which means that the test item has a very high degree of reliability so that it can be used and believed to be a measuring tool.

The questions used for the test are questions that meet the validity requirements, distinguishing power, and level of difficulty. The results of the instrument trial recapitulation of the 11 questions used in class XI IPA 2 SMA Negeri 9 Lubuklinggau, it can be concluded that the questions used for the pre-test and post-test are questions number 1,2,6,7,8,9 and 10 . Meanwhile, questions number 3,4,5 and 11 cannot be used, so the questions used for the pretest and post-test are 7 questions in the form of essays. The recapitulation of the analysis results can be seen in table 2 .

Table 2. Recapitulation of the results of the analysis of the instrument trial data

\begin{tabular}{|c|c|c|c|c|c|c|c|}
\hline \multirow{2}{*}{$\begin{array}{c}\text { No } \\
1 \\
\end{array}$} & \multirow{2}{*}{\multicolumn{2}{|c|}{$\begin{array}{l}\text { Validity } \\
\text { Valid/ Medium } \\
\end{array}$}} & \multicolumn{2}{|c|}{$\begin{array}{c}\text { Power } \\
\text { Differentiator } \\
\end{array}$} & \multicolumn{2}{|c|}{$\begin{array}{c}\text { Level } \\
\text { Trouble }\end{array}$} & \multirow{2}{*}{$\begin{array}{c}\text { Information } \\
\text { Used }\end{array}$} \\
\hline & & & 0,24 & Enough & 0,56 & Medium & \\
\hline 2 & 0.66 & Valid/ High & 0,20 & Enough & 0,32 & Medium & Used \\
\hline 3 & 0.19 & Invalid & 0,05 & $\mathrm{Bad}$ & 0,70 & Easy & Not Used \\
\hline 4 & 0.25 & Invalid & 0,09 & $\mathrm{Bad}$ & 0,20 & Hard & Not Used \\
\hline 5 & 0.24 & Invalid & 0,09 & $\mathrm{Bad}$ & 0,20 & Hard & Not Used \\
\hline 6 & 0.76 & Valid/ High & 0,24 & Enough & 0,30 & Medium & Used \\
\hline 7 & 0.61 & Valid/ High & 0,27 & Enough & 0,28 & Hard & Used \\
\hline 8 & 0.85 & Valid/ Very High & 0,33 & Enough & 0,42 & Medium & Used \\
\hline 9 & 0.65 & Valid/ High & 0,35 & Enough & 0,47 & Medium & Used \\
\hline 10 & 0.59 & Valid/ Medium & 0,25 & Enough & 0,24 & Hard & Used \\
\hline 11 & 0.01 & Invalid & $-0,01$ & Very Bad & 0,67 & Medium & Not Used \\
\hline
\end{tabular}


Arikunto also argues that "research design is a plan or design made by researchers as a description of the activities carried out" (Arikunto, 2006). The research method used in this study is a one-group pretest-posttest design. According to Sugiyono, the research design can be seen in table 3 (Sugiyono, 2012).

Table 3. Design Research

\begin{tabular}{ccc}
\hline Pre-test & Treatment & Post-test \\
\hline $\mathrm{O}_{1}$ & $\mathrm{X}$ & $\mathrm{O}_{2}$ \\
\hline
\end{tabular}

Description:

$\mathrm{O}_{1}=$ Pre-test

$\mathrm{O}_{2}=$ Post-test

$\mathrm{X}=$ Treatment of learning strategies

The research variable is the object of research or what is the point of attention of this study (Arikunto, 2010). This study has two variables, namely the independent variable and the dependent variable. Independent variables are variables that affect or cause the change or the emergence of the dependent variable (Sugiyono, 2015). The independent variable in this study is the Scientific approach. The dependent variable is the variable that is influenced or becomes the result, because of the independent variable. The dependent variable in this study is the student's physics learning outcomes.

This research was conducted at SMA Negeri 9 Lubuklinggau as a place that is the focus of research. Before conducting the research, the researcher begins the research by conducting a preliminary study or research observation to get to know the situation and condition of the school, physics subject teachers, and students. This research was conducted from 10 September to 10 October 2019.

The population in this research were all students who were used as a source of data in the study. Suharsimi suggests that the population is the whole object of research (Suharsimi, 2010). If someone wants to examine all the elements that exist in the research area, the research is a population study. Meanwhile, according to Sugiyono population is a generalization area consisting of objects or subjects that meet certain qualities and characteristics determined by research to be studied and then draw conclusions (Sugiyono, 2015). The population in this study were students of class X SMAN 9 Lubuklinggau. In detail the population is presented in table 4 .

Table 4. Population Class

\begin{tabular}{ccccc}
\hline No & Class & Male & Female & Total \\
\hline 1. & X IPA.1 & 13 & 23 & 36 \\
\hline 2. & X IPA. 2 & 16 & 20 & 36 \\
\hline 3. & X IPA. 3 & 14 & 22 & 36 \\
\hline 4. & X IPA. 4 & 10 & 26 & 36 \\
\hline & Total & 53 & 91 & 144 \\
\hline
\end{tabular}


Sampling in this study using a simple random sampling technique. Simple random sampling is a random sampling technique, regardless of the strata in the population (Sugiyono, 2012). Sampling is done by numbering the paper containing the population class number, then the paper is drawn and the paper that comes out is selected and taken as the sample, assuming all class $X$ has the same relative ability. The sample used in the study was class X IPA 2 which consisted of 36 students.

The data analysis technique was conducted to determine whether the hypothesis of the research results was accepted or rejected, then the data was tested using the t-test. Therefore, first looking for the average value and standard deviation of the initial test and final test, then perform the normality test and hypothesis testing. The normality test aims to determine whether the data is normally distributed or not. The calculation of the normality test for this distribution data uses the Chi-squared formula (Sugiyono, 2015). Furthermore, $\chi_{\text {hitung }}$ is compared against $\chi^{2}$ table for $\alpha=5 \%$ with degrees of freedom $(\mathrm{dk})=\mathrm{k}-1$, where $\mathrm{k}$ is the number of interval classes. If $\chi^{2}$ count $\geq \chi^{2}$ table, that means the data distribution is not normal and $\chi^{2}$ count $<$ $\chi^{2}$ table, meaning that the data is normally distributed.

Arikunto states that a hypothesis is a statement that has an important position in research (Arikunto, 2010). The hypothesis is a temporary answer proposed in research until proven through the collected data. It is said temporarily because the answers given are only based on relevant theories, not based on empirical facts obtained through data collection. Hypothesis testing will certainly conclude to accept or reject the hypothesis. Here is a hypothesis-testing formula using the t-test (Sugiyono, 2012). The hypothesis to be tested is:

$\mathrm{H}_{0}$ : The average student learning outcomes after participating in learning with the Scientific approach were less than $75\left(\mu_{\mathrm{o}}<75\right)$.

$\mathrm{H}_{\mathrm{a}}$ : The average student learning outcomes after participating in learning with the Scientific approach were greater than or equal to $75\left(\mu_{0} \geq 75\right)$.

\section{Results and Discussion}

In teaching and learning activity, the scientific approach includes some steps to be followed: observing, questioning, experimenting, associating, and communicating. According to Hosnan (2014), regarding scientific learning, "the implementation of 2013 Curriculum with the scientific approach is a learning process designed in such a way that learners can actively construct the concepts, laws, or principles through observing stages (to identify or find problems), formulate problems, propose or formulate hypotheses, collect data with various techniques, analyze data, draw conclusions and communicate concepts, laws or principles found (Yuniarti, 2018).

Implementation of a scientific approach requires a good relationship between teachers and students in the implementation of the learning process. This is an important factor in creating a fun learning environment and following the steps of the scientific approach. Teachers are required excellent communication skills. Patterns of communication between teachers and students is a pattern of communication that occurs between personal or interpersonal communication. This is consistent with a theory expressed by R. Wayne Pace was quoted by Cangara (2005) that "interpersonal communication is communication involving two or more people in a face to face setting". Furthermore, David Lazear in his book "Seven Ways of Teaching" as quoted by Arikunto (2012) states that one aspect that 
shows the intelligence aspect of a teacher is to develop students' personal psychomotor in interpersonal relationships. Thus, the ability to interact interpersonal very important to be understood and be used by teachers and students. Interaction communicative a wellestablished partnership between teachers and students will bring comfort students' learning and teachers in teaching that will bring a positive impact to the student learning outcomes evaluation (Saputri, 2018).

\section{Description of Pre-Test Data Analysis}

The initial students ' ability (pre-test) meant by this study was the initial knowledge that the students had before being given treatment with the scientific approach to the measuring material (Daryanto, 2014). Based on table 3, the pre-test average score is 22,63 with the highest score of 49 and the lowest score of 9 . This shows that there are no students who have scored more than or equal to the KKM score of 75.

Thus, the results of the pre-test before the implementation of physics learning using the Scientific approach are not yet complete. More details regarding the average value, greatest value, smallest value, the results of the student's initial test ability can be seen in table 5 .

Table 5. Recapitulation of Pre-Test Result Data

\begin{tabular}{cccccc}
\hline $\bar{x}$ & $S$ & $\begin{array}{c}\text { High } \\
\text { Score }\end{array}$ & $\begin{array}{c}\text { Low } \\
\text { Score }\end{array}$ & $\begin{array}{c}\text { students } \\
\text { who } \\
\text { completed }\end{array}$ & $\begin{array}{c}\text { students who } \\
\text { have not } \\
\text { finished }\end{array}$ \\
\hline 22,63 & 9,64 & 49 & 9 & $\begin{array}{c}0 \text { people } \\
(0 \%)\end{array}$ & $\begin{array}{c}36 \text { people } \\
(100 \%)\end{array}$ \\
\hline
\end{tabular}

Based on statistical calculation provisions on data normality test with $\alpha$ trust level $=0,05$. If $\chi^{2}$ count $<\chi_{\text {table, }}^{2}$ it can be declared that the data is a normal distribution. Test results of normality can be seen in table 6 :

\begin{tabular}{lcccc}
\multicolumn{6}{l}{ Table 6. Recapitulation of data normality test } \\
\hline Class & $\chi^{2}$ count & Dk & $\chi^{2}{ }_{\text {table }}$ & Explanation \\
\hline Eks & 6,1 & 5 & 11,1 & Normal \\
\hline
\end{tabular}

Table 4 above shows that $\chi^{2}$ count the pre-test data is smaller tha $\chi^{2}$ table. based on the provisions of the normality test using the suitability chi test $\left(\chi^{2}\right)$ It can be concluded that the data is normally distributed with a level of confidence $\alpha=5 \%$ or 0,05 and degrees of freedom $(\mathrm{dk})=5$.

\section{Description of Post-Test Data Analysis}

The Post-test was conducted to determine the student's final ability to the measuring material after obtaining the learning treatment using the Scientific approach. The description of the results of post-test data can be seen in table 7 . 
Table 7. Post Test Data Recapitulation

\begin{tabular}{cccccc}
\hline$\overline{\mathrm{X}}$ & $\boldsymbol{S}$ & $\begin{array}{c}\text { High } \\
\text { Score }\end{array}$ & $\begin{array}{c}\text { Low } \\
\text { Score }\end{array}$ & $\begin{array}{c}\text { students who } \\
\text { completed }\end{array}$ & $\begin{array}{c}\text { students who } \\
\text { have not } \\
\text { finished }\end{array}$ \\
\hline 81,16 & 8,53 & 95 & 60 & $\begin{array}{c}32 \text { people } \\
(88,00 \%)\end{array}$ & $\begin{array}{c}4 \text { people } \\
(12 \%)\end{array}$ \\
\hline
\end{tabular}

Based on table 5, it can be seen that the post-test average score is 81.16 with the highest score of 95 and the lowest score of 60 . This shows that 32 people or $88 \%$ of students have said it is complete because the score has reached the KKM, namely 75 . Four people or $12 \%$ of students have not completed it because their scores have not reached the KKM, so it can be concluded that the final ability of students in class X IPA 2 SMA Negeri 9 Lubuklinggau after implementing physics learning using a scientifically significant approach is complete.

Based on statistical calculation provisions on data normality test with $\alpha$ trust level $=0,05$. If $\chi^{2}{ }_{\text {count }}<\chi_{\text {table }}^{2}$, it can be declared that the data is a normal distribution. Test results of normality can be seen in table 8 .

Table 8. Recapitulation of data normality test

\begin{tabular}{lllll}
\hline Class & $\chi^{2}$ count & Dk & $\chi^{2}$ table & Explanation \\
\hline Eks & 8,05 & 5 & 11,1 & Normal \\
\hline
\end{tabular}

Table 8 shows that $\chi^{2}$ count on the post-test data is smaller than $\chi^{2}$ table. based on the provisions of the normality test using the suitability chi test $\left(\chi^{2}\right)$ It can be concluded that the data is normally distributed with a level of confidence $\alpha=5 \%$ or 0,05 and degrees of freedom $(\mathrm{dk})=5$. The average outcome of the learning submission value can be seen in Figure 1 .

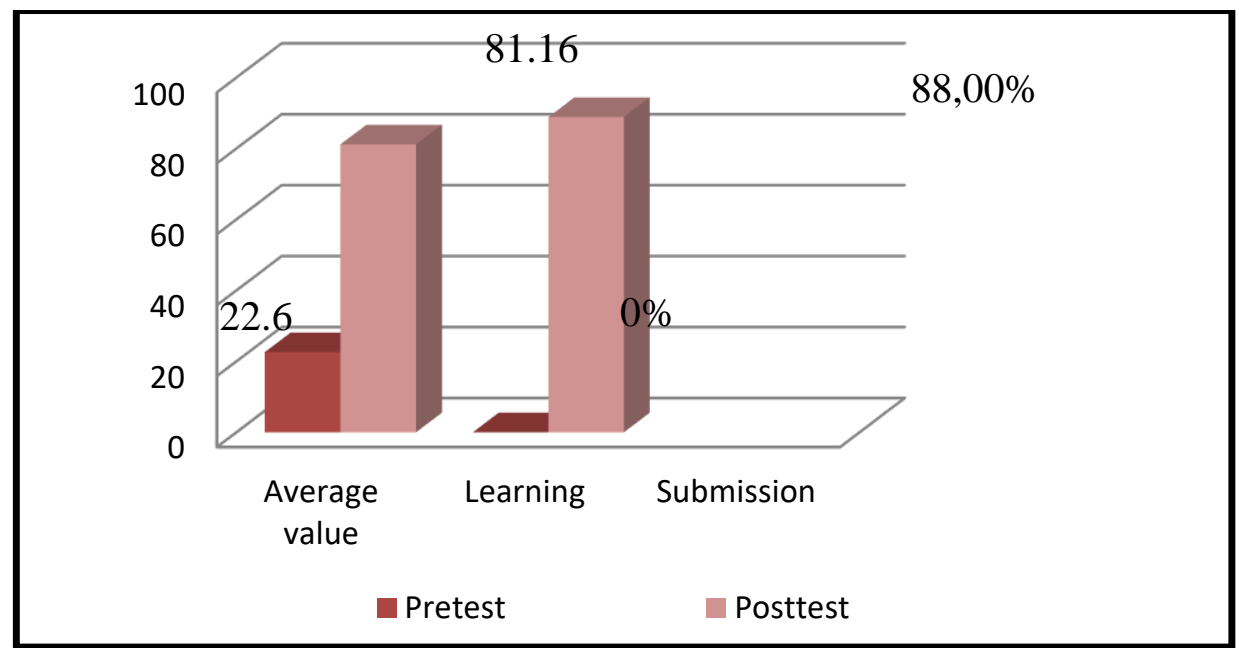

Figure 1. Avg. Chart Results Average learning value

To conclude the post-test data, the hypothesis is tested statistically. Based on the normality test, the data is normally distributed, so to test the hypothesis the t-test formula is 
used (Sundayana, 2014). Based on the calculation results, the recapitulation of the t-test results can be seen in Table 9.

Table 9. Recapitulation of t-test results

\begin{tabular}{ccc}
\hline tcount & ttable & Conclusion \\
\hline 4,33 & 1,697 & $H_{0}$ rejected dan $H_{a}$ received \\
\hline
\end{tabular}

Testing criteria $\alpha=0,05$ and $\mathrm{dk}=(36-1)=35$ then $\mathrm{t}_{\text {table }}$ amounting to 1,697 and $\mathrm{t}_{\text {count }}$ amounting to 4,33. Because $\mathrm{t}_{\text {count }}>\mathrm{t}_{\text {table }}$ then $H_{0}$ rejected dan $H_{a}$ received, it means that the truth of the hypothesis proposed in this study can be accepted, that the results of studying physics with the Scientific approach are significant complete (Aulia, 2017). Based on the research results described above, the following can be explained This research, which was conducted at SMA Negeri 9 Lubuklinggau, includes quasi-experimental research to find out whether student learning outcomes after participating in physics learning with a significant scientific approach are complete. The research was conducted in six (6) meetings, starting with giving a pre-test followed by learning physics using the Scientific approach for four meetings and ending with giving a post-test.

The learning process which is carried out using the Scientific approach of learning is applied to provide understanding to students in recognizing, understanding various materials using a scientific approach, that information can come from anywhere, anytime, and does not depend on one information from the teacher (Wahyuni, 2015). Learning with this Scientific approach allows all students to be more active and directly involved in the learning process, and this scientific approach makes them feel that the learning process is interesting and fun so that it does not cause boredom and students do not feel compelled. So it is hoped that learning with this scientific approach can make students more active in the learning process (Meuthia, 2015).

In the pre-test data analysis, an average $(22,63)$ and standard deviation $(9,64)$ were obtained that students of X IPA 2 students had not reached the completeness criteria score of 75. It was found that students of X IPA 2 scores low in the incomplete category, this is because the material has not been studied completely. The average student learning outcomes were $(81,16)$ and standard deviation $(8,53)$ then after the normality test the data were normally distributed. Judging from the completeness of the physics learning outcomes of students at SMA Negeri 9 Lubuklinggau with the completeness criteria (KKM) that has been set at 75 for physics lessons. In the experimental class, namely class X IPA 2 with a total of 36 students, of which 32 students $(88 \%)$ have completed or have reached the minimum completeness criteria (KKM), while 4 students (12\%) have not reached the KKM.

The conclusion is that $t$-table is 1,697 and $t$-count is 4,33 . Because $t_{\text {count }}>t_{\text {table }}$ then $H_{0}$ is rejected and $\mathrm{Ha}$ is accepted, meaning that the hypothesis proposed in this study can be accepted as true, that the results of studying physics with the Scientific approach are significant and complete (Marjan, 2014). This is following the results of (Hardianti, 2015) research, and concludes that the students who were taught using the Scientific approach had an average score of physics learning outcomes of 13,09, while students who were taught using 
conventional learning had an average score. physics learning outcomes of 8,22 . So it can be said that the Scientific approach has an important role in helping students achieve good results in the physics learning process (Nurfaizah, 2017).

\section{Conclusion}

Based on the results of the research and discussion previously described, it can be concluded that the average value of student learning outcomes is 81,16 and the research data obtained were analyzed by t-test, namely $t_{\text {hitung }}=4,33$ and $t_{\text {tabel }}=1,697$, because $t_{\text {hitung }} \geq t_{\text {tabel }}$ then $\mathrm{Ha}$ accepted and Ho rejected. With a percentage of completeness at least one can master $75 \%$ of the material being taught. Thus the hypothesis proposed in this study can be accepted as true or student learning outcomes after participating in physics learning using the Scientific approach in class X SMA Negeri 9 Lubuklinggau completely.

The limitations of this study are time constraints because students are not used to learning using the scientific approach and the number of meetings is shorter. It is hoped that further research will be able to increase the maximum number of meetings. The scope of research, because researchers limit research to the scientific approach in measuring and measuring matter. It is hoped that the next researchers will research other materials and with a wider scope.

\section{References}

Arikunto, S. (2006). Prosedur Penelitian Suatu Tindakan Praktik. Jakarta: Rineka Cipta.

Arikunto, S. (2010). Dasar-dasar Evaluasi Pendidikan. Jakarta: Bumi Aksara.

Aulia, N. P. (2017). Efektivitas Pendekatan Saintifik dalam Meningkatkan Pemahaman Konseptual pada Materi Pemisahan Campuran. Jurnal Pendidikan dan Pembelajaran Kimia, 130-144.

Aunurrahman, D. (2016). Belajar dan Pembelajaran. Bandung: Alfabeta.

Daryanto, D. (2014). Pendekatan Pembelajaran Saintifik Kurikulum 2013. Gava Media.

Hardianti. (2015). Peranan pendekatan scientific terhadap hasil belajar fisika peserta didik kelas x sma negeri 1 lappariaja. Jurnal Sains Dan Pendidikan Fisika, 34-39.

Marjan, J. (2014). Pengaruh Pembelajaran Pendekatan Saintifik Terhadap Hasil Belajar Biologi Dan Keterampilan Proses Sains Siswa MA. Mu Allimat NW Pancor Selong Kabupaten Lombok Timur Nusa Tenggara Barat. Jurnal Pendidikan dan Pembelajaran IPA Indonesia.

Meuthia, D. (2015). Efektivitas Pendekatan Saintifik Dalam Meningkatkan Kemampuan Membedakan Pada Materi Hidrolisis Garam. Jurnal Pendidikan dan Pembelajaran Kimia, 618-630.

Nenotaek, B. (2019). The Difficulties in Implementing Scientific Approach for Mathematics Learning. International Journal of Educational Research Review, 624-636.

Nurfaizah, N. (2017). Pelaksanaan pendekatan scientific pada pembelajaran fisika di SMA Negeri di Kabupaten Pidie. Jurnal Ilmiah Mahasiswa (JIM) Pendidikan Fisika, 299302.

Nurlatifah. (2019). Pengaruh Penerapan Pendekatan Saintifik Berbasis Eksperimen Terhadap Kemampuan Berpikir Kritis. jurnal Pendidikan Fisika uin-alauddin, 184-188. 
Purwadhi. (2019). Pembelajaran Inovatif dalam Pembentukan Karakter Siswa. Mimbar Pendidikan, 21-34.

Rhosalia, L. A. (2017). Pendekatan Saintifik (Scientific Approach). JTIEE.

Rusman. (2013). Belajar dan Pembelajaran Berbasis Komputer Mengembangkan Profesionalisme Guru Abad 21. Bandung: Alfabeta.

Rusman. (2019). Implementasi pembelajaran abad 21 dalam kurikulum 2013. Jurnal Penelitian Ilmu Pendidikan, 14-23.

Saputri, A. C. (2018). The Relationship between Scientific Approach and Science Teacher Interpersonal Interaction with Student Learning Outcomes in Junior High School. International Journal of Multicultural and Multireligious Understanding, 199.

Soenarto. (2011). Pengaruh Strategi Pembelajaran Dan Gara Berpikir Terhadap Hasil Belajar Fisika. Seminar Nasional Penelitian, Pendidikan dan Penerapan MIPA, Fakultas MIPA, Universitas Negeri Yogyakarta (pp. 98-108). Yogyakarta: Fakultas MIPA, Universitas Negeri Yogyakarta.

Sudirman, M. (2017). Improving Problem Solving Skill and Self Regulated Learning of Senior High School Students through Scientific Approach using Quantum Learning strategy. International Journal of Science and Applied Science: Conference Series, 249

Sugiyono. (2012). Statistik Untuk Pendidikan. Bandung: CV Alfabeta.

Sugiyono. (2015). Metode Penelitian. Bandung: Alfabeta.

Suharsimi, A. (2010). Prosedur Penelitian : Suatu Pendekatan Praktik. Jakarta: Rineka Cipta.

Wahyono. (2017). Implementation of Scientific Approach Based Learning to Think High Levels in State Senior High School in Ketapang. International Journal of Education and Research, 221-230.

Wahyuni, D. E. (2015). Implementasi Pembelajaran Scientific Approach dengan Soal Higher Order Thinking Skill pada Materi Alat-Alat Optik Kelas X di SMA Nahdlatul Ulama' 1 Gresik. Jurnal Inovasi Pendidikan Fisika (JIPF), 32-37.

Yuniarti, N. N. (2018). The Implementation of Scientific Approach with Project Based Learning Model to Improve Students' Analytical Skill and Responds. International Journal of Advanced Engineering Research and Science, 90-93. 